\title{
SISTEM PENGOLAHAN DATA PELANGGAN PADA TV KABEL PT. ANEKA VISION DUMAI MENGGUNAKAN VISUAL BASIC 6.0
}

\author{
Muhammad Riza Faisal ${ }^{1}$, Reza Fahlevie F.Afidh ${ }^{2}$, Adi Arianto ${ }^{3}$ \\ ${ }^{1,2,3}$ Sekolah Tinggi Manajemen Informatika dan Komputer (STMIK) Dumai \\ Jl.Utama Karya Kel.Bukit Batrem Kec.Dumai Timur, Dumai-Riau 28811 \\ e-mail : mrizafaisal3@gmail.com
}

\begin{abstract}
ABSTRAK
PT. Aneka Vision Dumai merupakan salah satu perusahaan yang bergerak di bidang jasa pelayanan TV kabel yang beralamat di Kota Dumai.PT. Aneka Vision Dumai, dimana permasalahan Pelanggan PT. Aneka Vision Dumai mengeluhkan dengan layanan perusahaan TV kabel di karenakan Pelanggan yang rajin membayar iuran TV kabel di kantor masih sering terjadi kesalahan dalam pencatatan data dan transaksi nya, serta seringkali terjadi kehilangan data dikarenakan masih dicatat pada buku besar dan semua transaksi masih di catat dengan menggunakan Microsoft excel yang mengakibatkan sulitnya perusahaan ini untuk menangani laporan. Penelitian ini membutuhkan sistem baru yang dikembangkan menggunakan bahasa pemrograman VISUAL BASIC 6.0. Sistem ini terhubung dengan database MySQL.Setelah diuji sistem ini tujuannya menangani proses pengelolaan data Teknisi, data pelanggan, data pelanggan menunggak, pendaftaran paket TV kabel dan melakukan transaksi pembayaran paket TV kabel.
\end{abstract}

Kata kunci : sistem pengolahan data pelanggan, visual basic 6.0, Mysql.

\section{PENDAHULUAN}

PT. Aneka Vision Dumai merupakan salah satu perusahaan yang bergerak di bidang jasa pelayanan TV kabel yang beralamat di Kota Dumai. Perusahaan ini salah satu media lokal yang khusus memberikan informasi dan serta pendidikan bagi masyarakat Kota Dumai dan memberikan siaran Televisi yang berkualitas dengan harga terjangkau. Untuk kedepan nya harapan PT. Aneka Vision Dumai ingin perusahaan nya dikembangkan dan memiliki cabang-cabang di Kota Dumai.

Pelanggan PT. Aneka Vision Dumai mengeluhkan dengan layanan perusahaan TV kabel di karenakan Pelanggan yang rajin membayar iuran TV kabel di kantor masih sering terjadi kesalahan dalam pencatatan data dan transaksi nya, serta seringkali terjadi kehilangan data dikarenakan masih dicatat pada buku besar dan semua transaksi masih di catat dengan menggunakan Microsoft excel yang mengakibatkan sulitnya perusahaan ini untuk menangani laporan. Hal ini tentu sangat memperlambatkan dan menyulitkan PT. Aneka Vision Dumai dalam menjalankan proses bisnisnya.
Penelitian ini membutuhkan sistem baruyang dikembangkan menggunakan bahasa pemrograman VISUAL BASIC 6.0. Disamping itu VISUAL BASIC 6.0 pengaksesan terhadap beberapa pustaka (library) di miliki oleh sistem windows, sintaks lebih mudah di pahami, fasilitas lebih lengkap mendukung user friendly dan multiuser. Sistem ini terhubung dengan database MySQL Setelah diuji sistem ini tujuannya menangani proses pengelolaan data Teknisi, data pelanggan, data pelanggan menunggak, pendaftaran paket TV kabel dan melakukan transaksi pembayaran paket TV kabel. Sistem dapat juga menangani laporan pemasukkan

pelanggan,laporanpembayaranpelanggan atau pelanggan yang telah membayar lunas dan laporan pelanggan yang menunggak.

\section{a. Pengertian Sistem}

Sistem adalah sekumpulan unsur atau elemen yang saling berkaitan dan saling mempengaruhi dalam melakukan kegiatan bersama untuk mencapai suatu tujuan.misalnya: sistemkomputeryangterdiridarisoftware,hardwar e,brainware(Indrianto, 2010). 
INFORM TIK A

Jurnal Informatika, Manajemen dan Komputer, Vol. 9 No. 1, Mei 2017

eISSN : 2580-3042

pISSN : 1979-0694

\section{b. Pengertian Pengolahan Data}

Pengolahan data adalah masa atau waktu yang digunakan untuk mendeskripsi perubahan bentuk data menjadi informasi yang memiliki kegunaan (M. Al' Amin1, 2015).

Ada beberapa operasi yang dilakukan dalam pengolahan data antara lain:

1. Data masukan, yaitu kumpulan data transaksi ke sebuah pengolahan data medium.

2. Data transformasi

3. Informasi keluaran, yaitu kegiatan untuk menampilkan informasi yang dibutuhkan pemakai melalui monitor atau cetakan.

Data adalah sekumpulan data yang telah dipilih untuk selanjutnya dipakai sebagai data yang akan dianalisa, untuk penelitian ini data yang dipakai adalah datadata alumni angkatan 2014 2015 STMIK Dumai(Asparizal \& Yunita, 2018).

\section{c. Pengertian Pelanggan}

Pelanggan adalah orang -orang yang kegiatannya membeli dan mengunakan suatu produk, baik barang maupun jasa, secara terus menerus. Secara garis besar terdapat tiga jenis pelanggan, yaitu pelanggan internal, pelanggan perantara, dan pelanggan eksternal(Singasatia \& Kom, M \& Pratiwi, Widian, D, 2010)

\section{d. Pengertian TV Kabel}

Sistem penyiaran acara televisi lewat isyarat frekuensi radio yang ditransmisikan melalui serat optik yang tetap atau kabel coasial dan bukan lewat udara seperti siaran televisi biasa yang harus di tangkap antena(over-the-air). Selain acara televisi, acara radio FM, internet, dan telepon juga dapat disampaikan lewat kabel.

Sistem ini banyak di jumpai di Amerika Utara,Eropa,Australia,Asia Timur, Amerika Selatan, dan Timur tengah. Sistem televisi kabel modern sekarang menggunakan teknologi digital untuk menyiarkan lebih banyak saluran televisi daripada sistem analog (Istanto, 1999)

Teknologi digital terintegrasi radio maupun televisi, mulai dari production line, transmiter hingga pesawat televisi. Pameran ini sekaligus merupakan proklamasi dari para industri bahwa mereka telah siap dengan teknologi digital mulai dari produksi di sudio hingga ke pesawat televisi. Ini sekaligus mencanangkan peralihan dari sistem analog ke digital(Mudjiyanto, 2013)

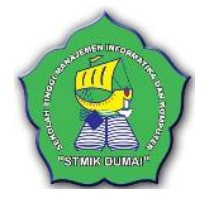

\section{e. Sejarah PT.ANEKA VISION Dumai}

18 November 2009 di Dumai dengan nama PT.Aneka Vision Dumai.sesuai dengan nama akta notaris APRILLIYA,SH,MKn yang berkendudukan di Dumai NO AHU-30.0201.TAHUN 2009 Tanggal 12 Januari 2009.

Pendirian Badan hukum PT ini sesuai dengan regulasi yang berlaku untuk bidang usaha Penyiaran yang pada UU no 32 tahun 2002 bahwa badan hukum harus berbentuk Perseroan Terbatas dengan spesifik bidang usahanya Penyiaran.

\section{f. Visual Basic 6.0}

Merupakan salah satu sofware pembuat komputer aplikasi yang sangat handal hingga saat ini. Software ini diambil dari nama bahasa pemograman .

Visual basic adalah bahasa pemograman yang digunakan untuk membuat aplikasi windows yang berbasiskan grafis. Bahasa pemograman adalah perintah-perintah atau instruksi-instruksi yang dimengerti oleh computer untuk melkukan tugas-tugas tertentuMengenal Lingkungan Visual Basic 6.0(Susanti, 2016):

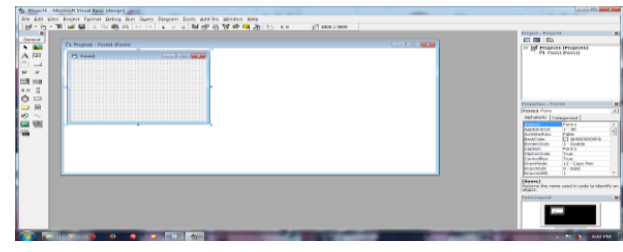

Gambar 1. Kontrol pada Visual Basic 6.0

\section{Control menu}

Control menu adalah menu ynag digunakan terutama untuk memanipulasi jendral Visual Basic . Antara lain :

Restrore : mengubah ukuran jendela ke ukuran sebelumnya.

Move : untuk memindahkan letak jendela

Size : untuk mengubah ukuran jendela

Minimize : untuk meminimalkan ukuran jendela Maxsimal :untuk maksimalkan ukuran jendela

Close :untuk menutup jendela

2. Menu bar

Menubar adalah tempat dimana seluruh perintah(menu) ditempatkan secarahirarki. 
IN F ORM A I I A

Jurnal Informatika, Manajemen dan Komputer, Vol. 9 No. 1, Mei 2017

elSSN : 2580-3042

pISSN : 1979-0694

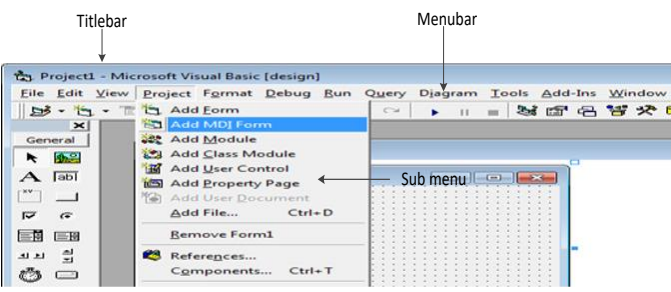

Gambar 2. Menu dan sub menu

3. Toolbar

Toolbar adalah tempat sekumpulan tool yang merupakan ciri aplikasi berbasic windows

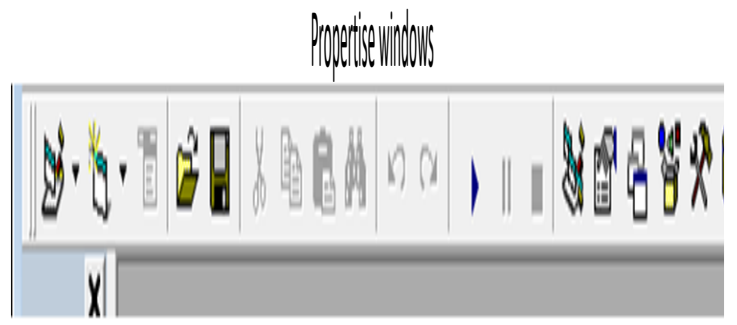

Gambar3.Toolbar

4 Toolbox

Toolbox berada disebelah kiri tampilan, terdiri dari beberapa icon untuk membuat kontrol dalam form.

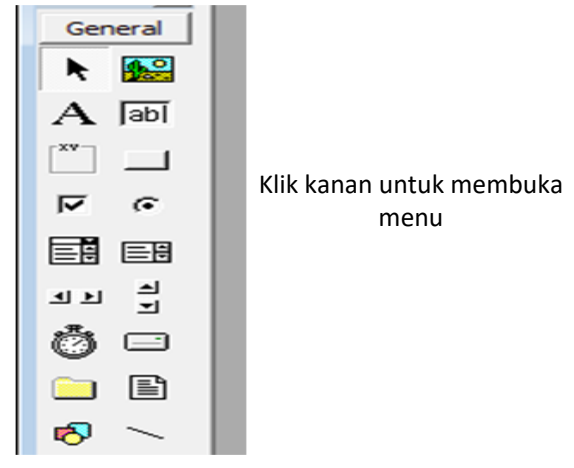

Gambar 4. Toolbox

\section{g. MySQL}

MySql merupakan software yang tergolong database server dan bahwa software ini dilengkapi dengan source code (kode yang di pakai untuk membuat MySql), selain tentu saja bentuk executable nya atau kode yang dapat dijalankan secara langsung dalam sistem operasi, dan bisa di peroleh dengan cara mengunduh di internet secara gratis(Riksandriyo, 2013).
MySQLadalah suatu jenis databaseserveryang sangat terkenal dan banyak digunakan untuk membangun aplikasi webyang banyak mengunakan database sebagai sumber dan pengelolaan datanya.

Kepopuleran MySQLantara lain karena MySQL menggunakan SQLsebagai bahasa dasar untuk mengakses databasenya sehinggah mudah untuk digunakan, kinerja querycepat, dan mencukupi untukkebutuhandatabasedanperusahaanperusaha an skala menengah kecil(Arianto, Pratiwi, \& Adrianto, 2018)

\section{h. XAMPP}

Xampp merupakan singkatan dari X (empat sistem operasi apapun), Apache, Mysql, PHP, dan Perl. Xampp adalah tool yang menyediakan paket perangkat lunak dalam satu buah paket. Dalam paket Xampp sudah terdapat Apache (web server), Mysql (database), PHP (server side scripting), Perl ,FTP server, PhpMyAdmin dan berbagai pustaka bantu lainya. Menurut Herny Februariyanti dan Eri Zuliarso dalam jurnal (2012,h:129), XAMPP merupakan software yang mudah digunakan, gratis dan mendukung instalasi di linux dan windows. Keuntungan lainnya adalah Cuma menginstal satu kali sudah tersedia Apache Web Server, MySQL Database server dan beberapa module lainnya(Hendrianto, 2014)..

\section{g. Kerangka Berfikir Penelitian}

Konsep dasar pemilihan topik permasalahan dan perumusan masalahnya yang didasarkan pada alur yang digambarkan dalam skema hubungan antara objek-objek yang diteliti sehingga dapat menjelaskan antara sistem masukan dan keluaran sistem. Kerangka pemikiran dalam penelitian dapat dilihat pada gambar dibawah ini:

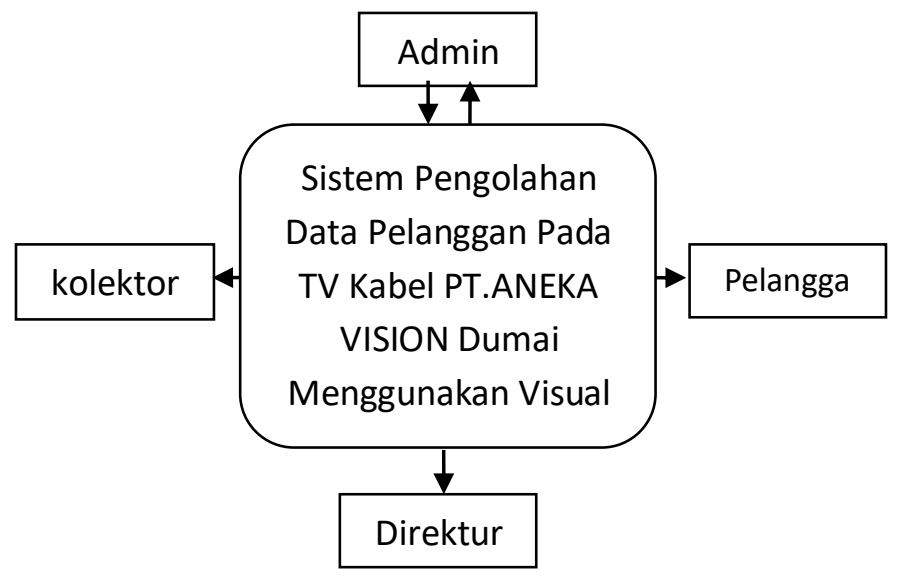

Gambar 5. Kerangka Pemikiran 
IN F ORM A I I A

Jurnal Informatika, Manajemen dan Komputer, Vol. 9 No. 1, Mei 2017

elSSN : 2580-3042

pISSN : 1979-0694

\section{METODOLOGI PENELITIAN}

Kerangka penelitian yang digunakan dalam penelitian ini adalah sebagai berikut :

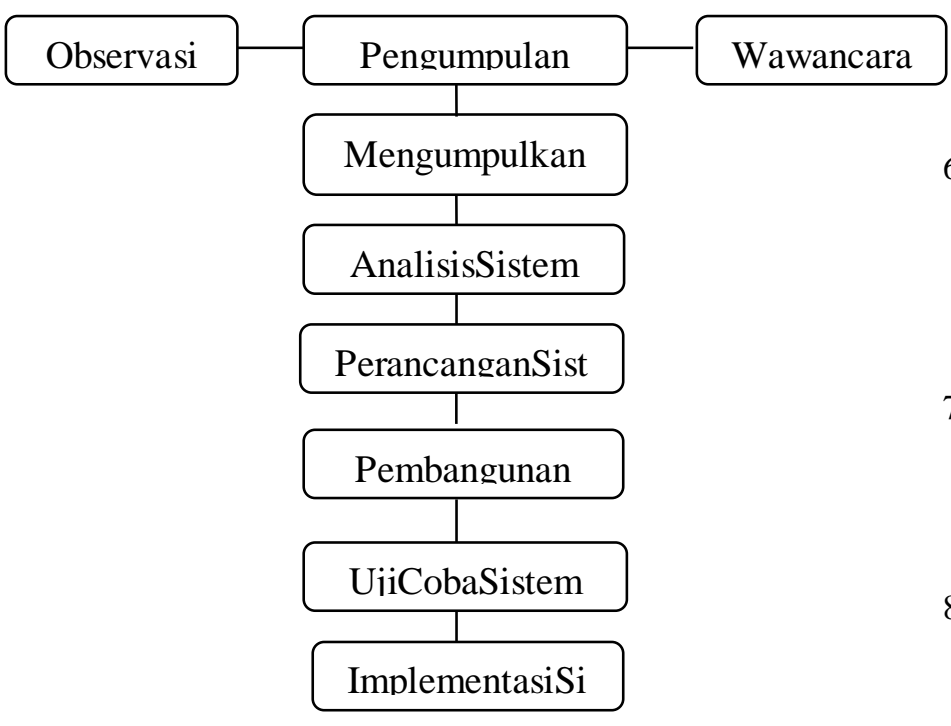

Gambar 6. Kerangka Penelitian

Berdasarkan gambar 6 dapat dijelaskan bahwa:

1. Pengumpulan data

Yaitu tahapan pengumpulan data melalui pendekatan ke lapangan dengan mengambil data-data yang terjadi di lapangan atau melakukan peninjauan secara langsung ke objek yang di teliti yaitu:

2. Observasi

yaitu dengan melakukan kunjungan lansung di kantor PT. Aneka Vision Dumai untuk mendapatkan data-data yang di perlukan serta mempelajari langsung kasus yang terjadi dilapangan.

3. Interview

yaitu dengan melakukan wawancara Direktur PT. Aneka Vision Dumai serta pihak-pihak yang terkait dengan permasalahan yang di bahas dalam penelitian ini.

4. Mengumpulkan Referensi

Yaitu penelitian yang dilakukan untukmendapatka sumber referensi yang berhubungan dengan buku-buku mengenai komputer, bahasa pemograman, metode penelitian, database, maupun buku umum lainnyayangberhubungandenganpenelitianun tukpembangunan $\mathrm{p}$ rogram aplikasi.
5. AnalisisSistem

Analisis data pada penelitian ini menggunakan metode deskriptif, yaitumetode yang menggambarkan suatu keadaan atau permasalahan yang sedang terjadi berdasarkan faktadan data-data yang diperoleh dan dikumpulkan pada waktu melaksanakan penelitian di PT. Aneka Vision Dumai

6. Perancangan Sistem

Pada tahap ini dilakukan proses desain system dimulai dengan penyajian basis data, perancangan aliran system informasi, DFD, context diagram, ERD, desain input, desain output, dan perancangan file.

7. Pembangunan Sistem

Sistem informasi dibangun dengan menggunakan bahasa pemograman VB 6.0 dengan Database MySQL berdasarkan perancangan system yang telah dirancang.

8. UjiCoba Sistem

Uji coba pada system pengolahan data pasienrawatjalan dengan tujuan untuk mengetahui kesalahan atau adanya koneksi yang tidak terhubung, sehingga sistem pengolahan data TV kabel di PT. Aneka Vision Dumai dapat berjalan dengan sempurna.

9. Implementasi Sistem

Suatuproses untuk menempatkan sistem informasi baru ke PT. Aneka Vision Dumai yang sudah ada sistem lama nya .

\section{HASIL DAN PEMBAHASAN}

a. Aliran Sistem Informasi Yang Sedang Berjalan

Sebelum dilakukan perancangan sistem yang baru, terlebih dahulu dilakukan analisis terhadap sistem yang telah berjalan saat ini. Hal ini bertujuan untuk membandingkan kinerja sistem yang telah ada dengan sistem yang akan diusulkan.

Adapun sistem yang berjalan saat ini pada PT. Aneka Vision adalah Kesulitan Pelanggan dalam melakukan pendaftaran dan pembayaran di karenakan belum adanya sistem pendaftaran dan pembayaran, penerbitan laporan pelanggan dan layanan service yang relatif lambat dan sering terjadi kesalahan, hal ini disebabkan penyusunan laporan masih manual dan dikerjakan dengan perhitungan manusia yang di padukan dengan bentuk Microsoft Excel (belum tersistem dan terintegrasi), sehingga dalam pengelolaan datanya sedikit mamakan waktu 
INFORM T IK

Jurnal Informatika, Manajemen dan Komputer, Vol. 9 No. 1, Mei 2017

eISSN : 2580-3042

pISSN : 1979-0694

yang menakibatkan penyajian laporan menjadi terlambat.

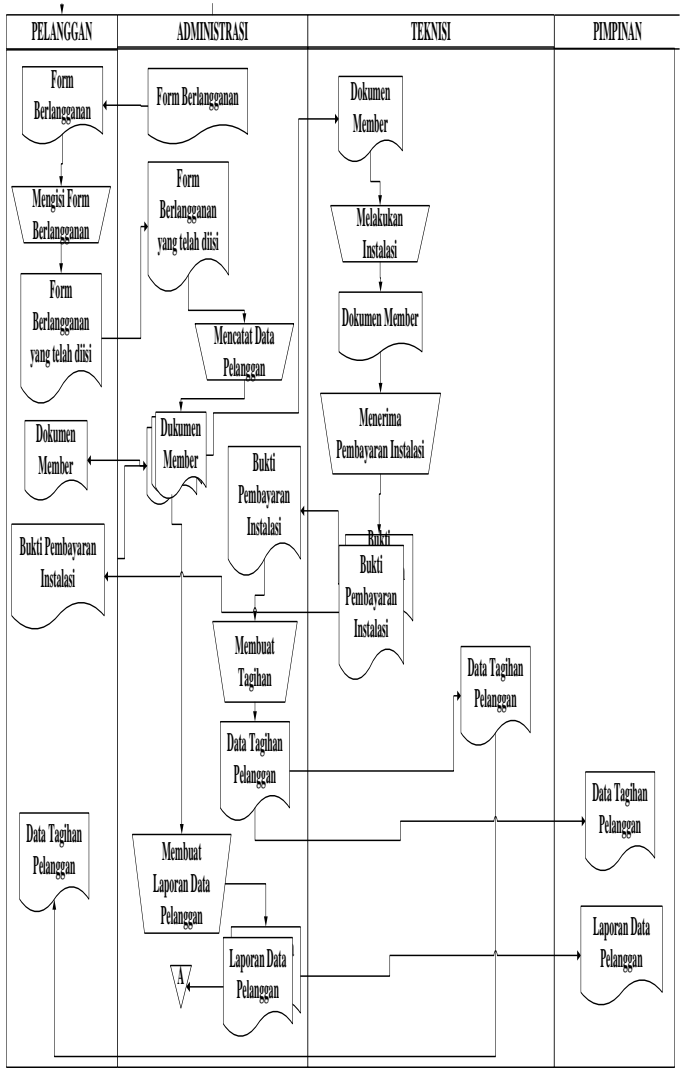

Gambar 7. Aliran Sistem Informasi Yang Sedang Berjalan

Untuk alur data sistem yang sedang berjalan akan diuraikan menggunakan Aliran Sistem Informasi. Aliran Sistem Informasi yang sedang berjalan dapat dilihat pada gamabr 3.1 sebagai berikut:

1. Pelanggan mengambil formulir lalu mengisi data form yang diberikan atau dipilih oleh pelanggan.

2. Lalu administrasi mencatat data pelanggan dan pemasangan, selanjutnya administrasi memberikan kepada bagian Teknisi

3. Setelah data di terima dari bagian administrasi lalu memasang perangkat layanan sesuai dengan permintaan pelanggan

4. Pelanggan membayar biaya pemasangan kepada bagian teknisi lalu bagian teknisi memberikan bukti pembayara kepada bagian administrasi.

5. Setelah itu bagian administrasi membuat tagihan pembayaran ketika sudah masuk tanggal pembayaran kepada bagian teknisi.
6. Bagian teknisi melakukan penagihan kepada pelanggan

7. Setelah itu bagian teknisi memberikan kepada administrasi

8. Setelah itu administrasi memberikan data pelanggan dan data pembayaran pelanggan kepada pimpinan.

\section{b. Aliran Sistem Informasi (Sistem Baru)}

Berdasarkan hasil analisis sistem yang sedang berjalan semua kebutuhan-kebutuhan sistem telah dipertimbangkan dalam desain sistem, bertujuan untuk memberikan gambaran kepada sistem analisis pembuatan program mengenai masukan (input) ke dalam proses dan apa yang akan dihasilkan keluaran (output). Adapun input dalam sistem yang diusulkan adalah input data pelanggan, data teknisi, data paket sedangkan untuk prosesnya data registrasi pelanggan baru pembayaran tagihan pelanggan, data penunggakan serta laporan-laporan pelanggan dan pembayaran.

1. Pelanggan mengambil formulir lalu mengisi data form yang diberikan atau dipilih oleh pelanggan.

2. Lalu administrasi menginputkan secara komputerisasi data pelanggan dan pemasangan, selanjutnya administrasi memberikan kepada bagian Teknisi

3. Setelah data di terima dari bagian administrasi lalu memasang perangkat layanan sesuai dengan permintaan pelanggan

4. Pelanggan membayar biaya pemasangan kepada bagian teknisi

5. lalu bagian teknisi memberikan bukti pembayaran kepada bagian administrasi.

6. Setelah itu bagian administrasi membuat tagihan pembayaran ketika sudah masuk tanggal pembayaran kepada bagian teknisi.

7. Bagian teknisi melakukan penagihan kepada pelanggan

8. Setelah itu bagian teknisi memberikan kepada administrasi

9. Setelah itu administrasi memberikan data pelanggan dan data pembayaran pelanggan kepada pimpinan. 
INFORM T IK

Jurnal Informatika, Manajemen dan Komputer, Vol. 9 No. 1, Mei 2017

eISSN : 2580-3042

pISSN : 1979-0694

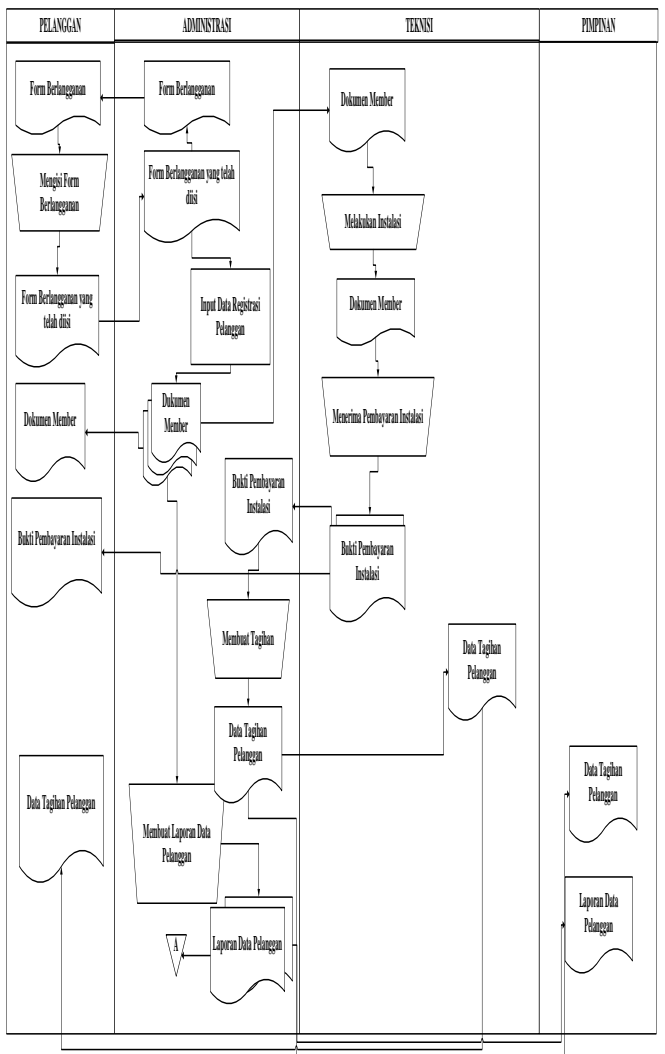

Gambar 8.Aliran Sistem Informasi Baru

\section{c. Context Diagram}

Ada pun diagram konteks sistem yang akan dibangun dapat dilihat pada gambar 9 berikut.

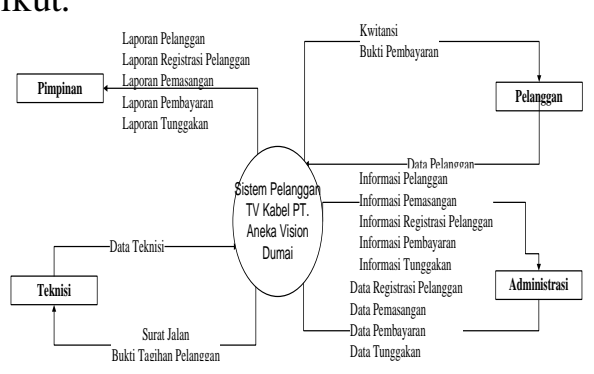

Gambar 9. Context Diagram

\section{d. DFD (Data Flow Diagram)}

Berikut merupakan data flow diagram dari sistem yang dibangun .

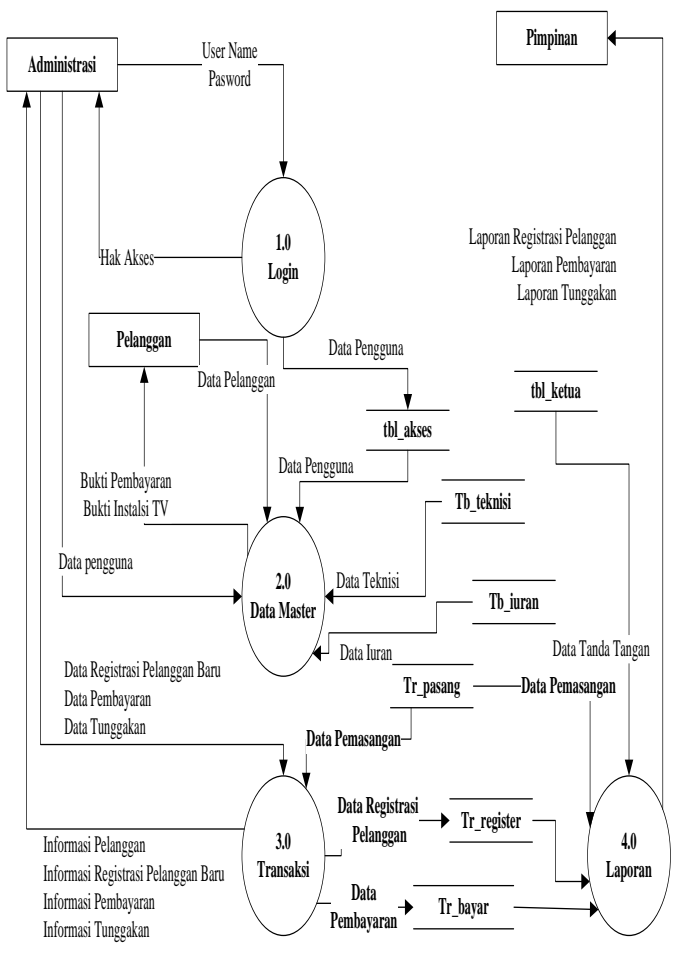

Gambar 10. Data Flow Diagram

e. Entity Relationship Diagram (ERD)

Entity Relationship Diagram dapat membantu kita dalam mempelajari hubungan antar file database yang kita rancang.Berikut gambar 11menggambarkan Entity Relationship Diagram pengolahan data pelanggan.

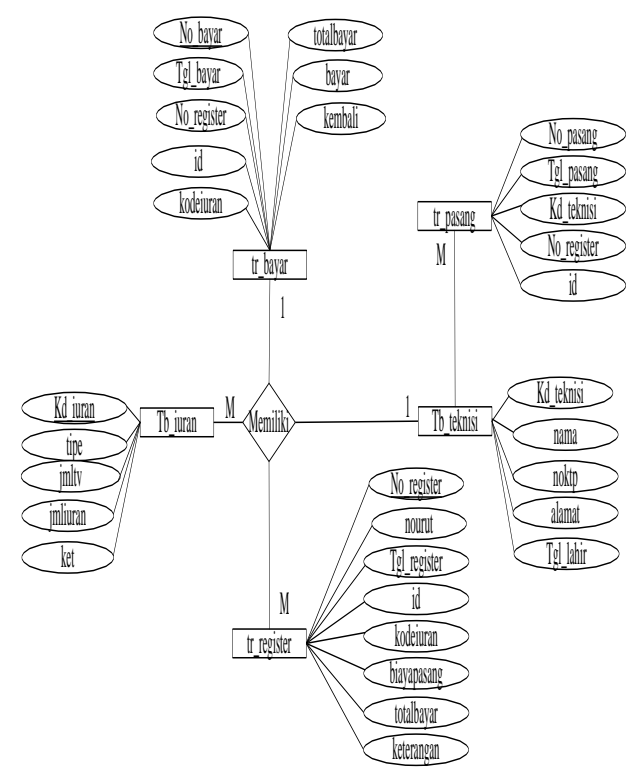

Gambar 11.ERD dari sistem yang dibangun 
INFORM $\mathrm{O}$ T I K

Jurnal Informatika, Manajemen dan Komputer, Vol. 9 No. 1, Mei 2017

eISSN : 2580-3042

pISSN : 1979-0694

f. Flowchart

1. Flowchart Login

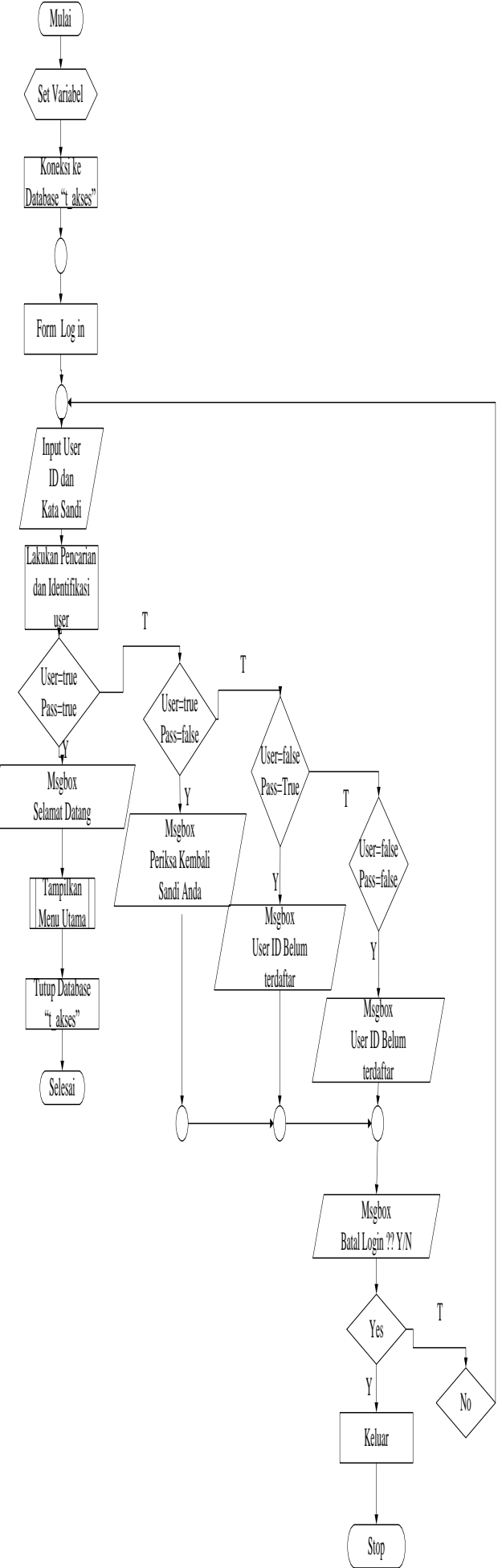

Gambar 12. Flowchart Login

2. Flowchart Data Registrasi Pelanggan

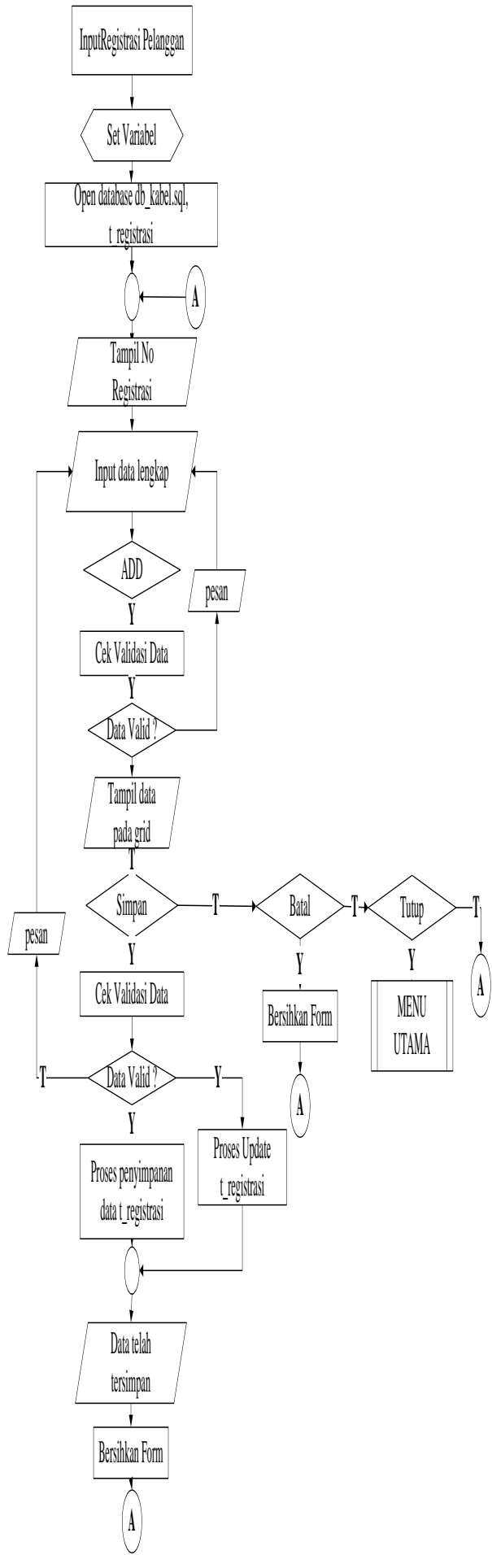

Gambar 13. Flowchart Data Registrasi Pelanggan 
IN F ORM A I I A

Jurnal Informatika, Manajemen dan Komputer, Vol. 9 No. 1, Mei 2017

eISSN : 2580-3042

pISSN : 1979-0694

\section{g. Hierarki Input Proses Output}

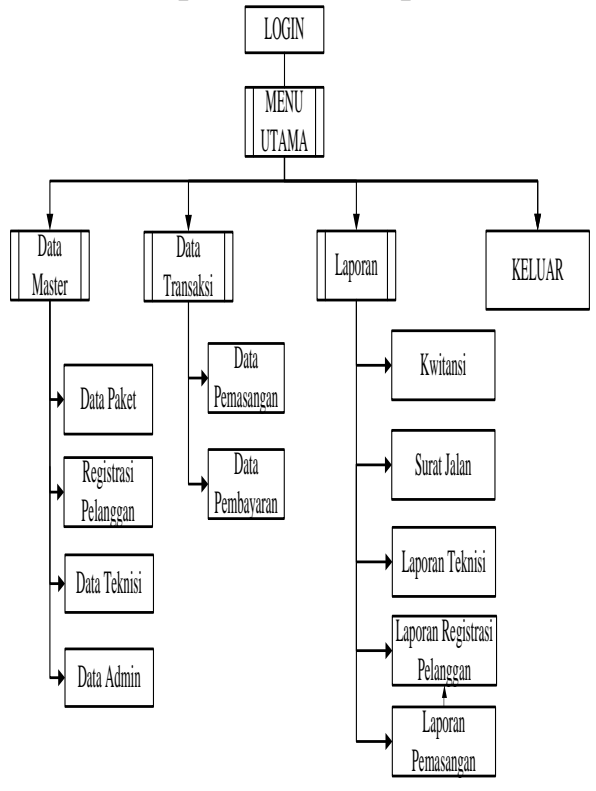

Gambar 14.Hierarki Input Output

\section{h. Implementasi Sistem}

1. Form Login Aplikasi

Form Login merupakan langkah pertama dalam mengimplementasikan program untuk masuk ke menu utama.

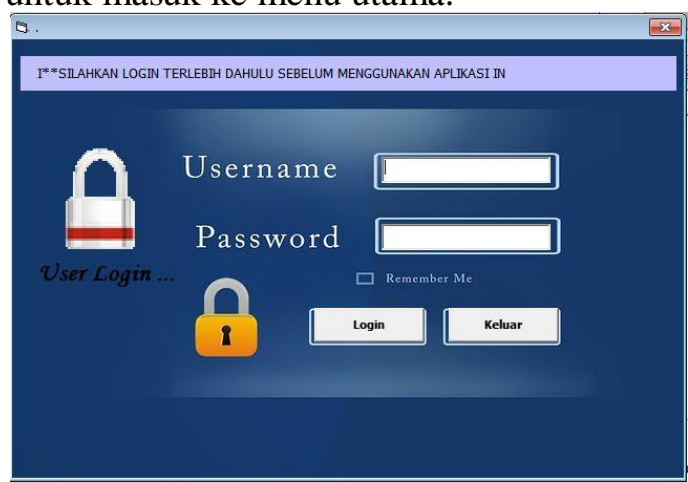

Gambar 15. Form Login Aplikasi

Masukkan username dan password yang sudah ada di database. Sistem ini memiliki 2 hak akses yaitu hak akses untuk admin, Operator. Admin bertanggung jawab atas sistem dalam mengakses dan melakukan penginputan data pelanggan. Sedangkan Operator hanya melihat semua laporan data pada sistem. Pada halaman login, Jika username dan password benar maka akan terbuka halaman menu utama, jika username dan atau password salah maka akan kembali ke halaman form login.
2. Form Menu Utama

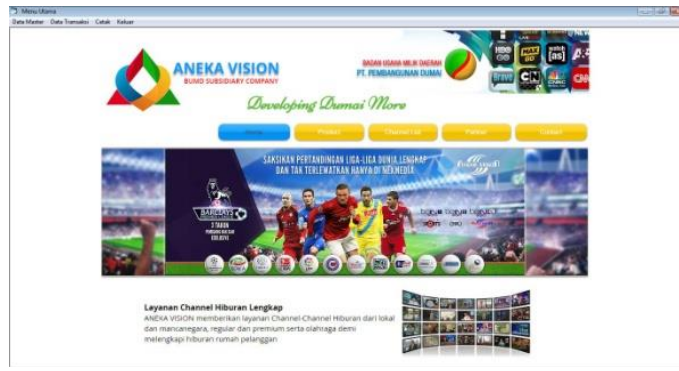

Gambar 16. Form Menu Utama

Didalam menu utama Admin terdapat menu-menu yang memiliki fungsi masingmasing, yaitu menu data master, data transaksi, laporan, dan keluar . Pada menu data master berfungsi untuk menambah, mengedit, dan menghapus hak akses program. Didalam menu master terdapat sub menu data paket, data registrasi pelanggan, data teknisi, dan data admin didalam data transaksi terdapat sub menu data pemasangan, dan data pembayaran. Didalam menu laporan terdapat laporan kwntasi, surat jalan, laporan teknisi, laporan registrasipelanggandanlaporan pemasangan. serta logout untuk keluar dari sistem.

3. Form Input Data Registrasi Pelanggan

Pada menu Data Master klik submenu Registrasi Pelanggan dan akan tampil form input Pelanggan sebagai berikut :

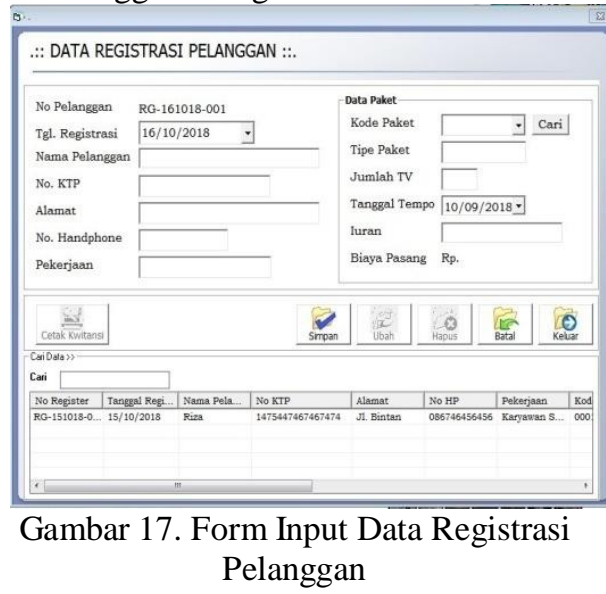

1. Kemudian silahkan input data pada setiap objek yang ada di form kemudian klik tombol SIMPAN. 
IN F O RM A T I A

Jurnal Informatika, Manajemen dan Komputer, Vol. 9 No. 1, Mei 2017

elSSN : 2580-3042

pISSN : 1979-0694

2. Jika untuk mengedit data silahkan isi klik data Pelanggan yang ingin dikoreksi pada listview kemudian lakukan pengeditan dengan cara klik pada tombol

\section{UBAH.}

3. Untuk menghapus data Pelanggan silahkan klik tombol HAPUS untuk menghapus data dari database.

4. Untuk membatalkan penginputan data silahkan klik tombol BATAL.

5. Untuk keluar dari form ini klik tombol KELUAR

4. Form Input Data Paket

Pada form input Data Paket ini digunakan untuk melakukan penginputan data Paket, adapun cara penginputannya adalah sebagai berikut:

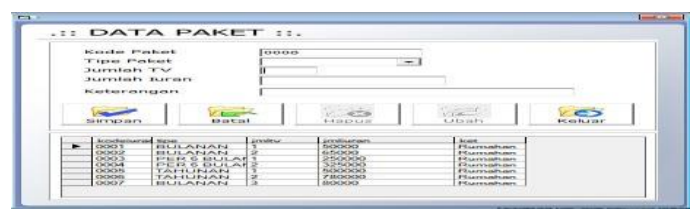

Gambar 18. Form Input Data paket

1. Kemudian silahkan input data pada setiap objek yang ada di form kemudian klik tombol SIMPAN

2. Jika untuk mengedit data silahkan pilih data yang ingin dikoreksi di listview kemudian lakukan pengeditan dengan cara klik pada tombol UBAH

3. Untuk menghapus data jenis kamar silahkan klik tombol HAPUS untuk menghapus data dari database.

4. Untuk membatalkan penginputan data silahkan klik tombol BATAL.

5. Untuk keluar dari form ini klik tombol KELUAR

i. Output Sistem

1. Laporan Registrasi Pelanggan

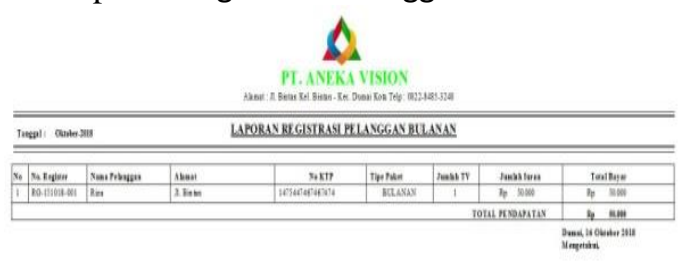

Gambar 19. Laporan Registrasi Pelanggan

2. Laporan Pemasangan

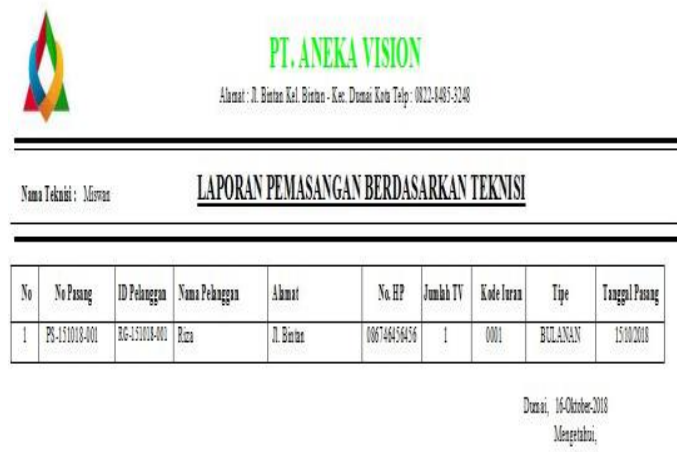

Dnslimugriman

Gambar 20. Laporan Pemasangan

3. Laporan Kwintasi

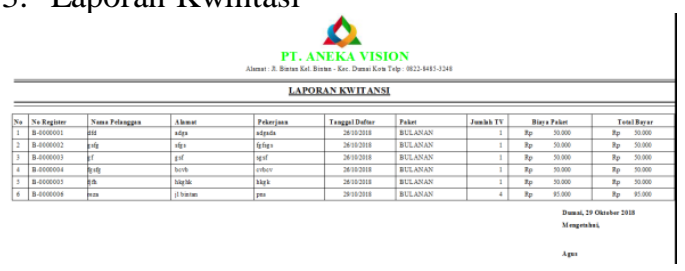

Gambar 21. Laporan Kwintasi

4. Laporan Surat Jalan

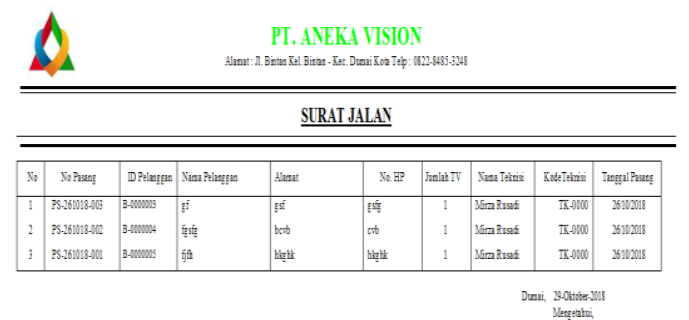

Gambar 22. Laporan Surat Jalan

5. Laporan Teknisi

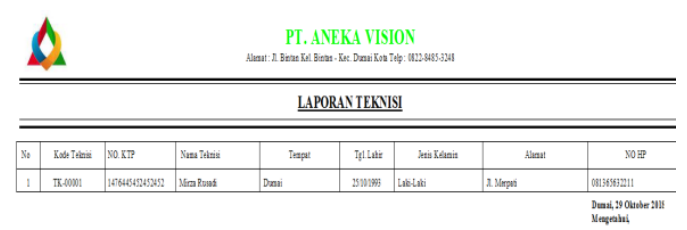

Gambar 23. Laporan Teknisi 
IN F ORM A I I A

Jurnal Informatika, Manajemen dan Komputer, Vol. 9 No. 1, Mei 2017

eISSN : 2580-3042

pISSN : 1979-0694

\section{KESIMPULAN}

Pelayanan dan penyajian informasi yang cepat, tepat dan akurat sangat penting sekali bagi pertumbuhan atau pekembangan suatu organisasi atau instansi-instansi. Searah dengan perkembangan ilmu pengetahuan teknologi yaitu dengan munculnya sistem pengelolahan data dengan penggunaan komputer sangat membantu sekali dalam mendapatkan informasi yang cepat,tepat dan akurat .

Berdasarkan penelitian yang telah dilakukan dengan mengamati dan menganalisa sistem pengelolahan data digunakan serta dilandasi oleh teori-teori dan alat-alat yang digunakan berkaitan dengan penelitian, maka dapat disimpulkan dan dapat dirasakan bahwa perlu diterapkan dan dilaksanakan sistem komputer dengan menggunakan suatu paket aplikasi komputer. Yang mana nantinya dapat menggantikan sistem lama yang ditangani secara manual. Maka berdasarkan uraian-uraian diatas dan perancangan sistem yang dimaksud tersebut dalam skripsi ini, maka dapat diambil beberapa kesimpulan yaitu :

1. Bahwa sistem komputerisasi adalah sarana pendukung yang efektif dan efisien dalam menyelesaikan suatu pekerjaan pengelolaan data dengan jumlah yang banyak.

2. Transaksi pembayaran TV Kabel menjadi semakin cepat dan mudah serta pembuatan bukti administrasi pembayaran seperti kwitansi pembayaran menjadi lebih praktis

3. Penyimpana data-data seperti data Pelanggan, dan data lainnya lebih aman dan ekonomis didukung oleh layanan pencarian data yang memberikan kemudahan, kecepatan, dan ketepatan yang lebih.

4. Informasi disampaikan tidak lagi secara lisan (person to person) melainkan dengan bukti sistem pengelolahan data Pelanggan yang akurat.

\section{REFERENSI}

Arianto, A., Pratiwi, F., \& Adrianto, S. (2018). Sistem Pengolahan Data Nilai Siswa Berstandar Kurikulum 2013 Di SMP Negeri 2 Dumai. SATIN - Sains Dan Teknologi Informasi, 4(1), 80-88.

Asparizal, \& Yunita, P. (2018). Implementasi Algoritma C4.5 dalam Memprediksi Masa
Studi Mahasiswa STMIK Dumai. Asparizal. Asparizal, P. Yunita. (N.d.). Implementasi Algoritma C4.5 Dalam Memprediksi Masa Studi Mahasiswa STMIK Dumai. Asparizal., 91-99.

Hendrianto, D. E. (2014). Pembuatan Sistem Informasi Perpustakaan Berbasis Website Pada Sekolah Menegah Pertama Negeri 1 Donorojo Kabupaten Pacitan. Hendrianto, 3(4), 57-64. https://doi.org/10.1123/IJNS.V4I3.288

Indrianto. (2010). Pembuatan Sistem Antrian Berbasis Sensor Infra Merah. Sekolah Tinggi Teknik - PLN, 1-14.

Istanto, F. H. (1999). Peran Televisi Dalam Masyarakat Citraan Dewasa Ini Sejarah, Perkembangan, Dan Pengaruhnya. Nirmana, 1(2), 95-108.

M. Al' Amin1, M. (2015). Aplikasi Pembayaran Administrasi Siswa Pada SMK Al Falah Songgom Brebes dengan Visual Basic. Jurnal Teknik Informatika Dan Sistem Informasi, 1(3), 245-252.

Mudjiyanto, B. (2013). Sikap penyelenggara siaran televisi terhadap penyelenggaraan siaran televisi digital television broadcaster attitude toward digital television broadcasting, 123-134.

Riksandriyo. (2013). Aplikasi Sistem Pengolahan Data Penjualan Dan Profit Pada Traffix Distro Pacitan. Indonesian Jurnal on Computer Science - Speed IJCSS, Vol 10(No 4), Hal 24-33.

Singasatia, D., \& Kom, M \& Pratiwi, Widian, D, S. (2010). Sistem informasi pelayanan pelanggan baru, 103-106.

Susanti, F. (2016). Sistem Pengelolaan Pembayaran Kredit Barang Pada Cv.Karya Tiasa Anugerah, 1-19. 